\title{
조류 인플루엔자 및 각국의 지원 동향
}

\section{1. 인도네시아 조류 인플루엔자 동향}

- 3.9 일 현재 인도네시아 보건부에 따르면 현재 까지 조류 인플루엔자로 인한 사망자는 총 21 명이며 3.4 일 숨진 10 세 소년의 사망 원인도 조 류 인플루엔자 감염으로 밝혀질 경우 22 명이 될 것이라 함.

- 특히 지난 2003년 하반기에 조류 인플루엔 자로 인한 첫 사망자가 발생한 이래로 2005 년까지 총 12 명이 사망하였으나 2006년에 들어와 2 개월 동안 9 명이 발생하는 등 조류 인플루엔자로 인한 사망자가 급속히 증가되 는 추세임. (치사율 $75 \%$, 총 28 명 감염자중 21 명 사망)

- 또한 현재 조류 인플루엔자로 감염 의심으로 치료 받고 있는 환자는 8명임.

- 주재국 보건부는 인체간 감염 사례가 없음을 주장하고 있으나 $\mathrm{WHO}$ 등 관련 국제기구는 인체간 감염 가능성을 우려하고 이를 지속적 으로 경고하고 있는 상황임.
- 지난 2월에 주재국 보건부는 조류 인플루엔자 치료 효과가 있는 것으로 밝혀진 타미플루를 전국 4,000 개 보건소에 보건소당 100 정씩 총 400,000 정을 배포했음.

- 시티 파닐라 보건장관은 3월말까지 타미플 루를 추가로 150 만정을 확보하고 앞으로도 지속적으로 확보 추진하여 총 1 천 200만정을 비축할 계획임을 밝힘.

- 조류 인플루엔자 대책 예산

- 바크리 복지담당 조정장관은 주재국이 향후 조류 인플루엔자의 예방과 근절을 위하여 총 $\mathrm{US} \$ 9$ 억이 소요될 것으로 예상된다고 밝힘.

- 동 장관은 주재국의 조류 인플루엔자 예산 배정 계획은 향후 3 년간 US $\$ 6$ 천만 정도이며 나머지 US\$ 8억 4천만은 각국의 지원으로 충당하겠다는 입장을 밝힌 바 있음.

※ 현재까지 국제사회에서 주재국에 지원하거나 지원 계획을 밝힌 금액은 US\$ 1억 4천만 정도임. 


\section{2. 각국 지원 동향}

\section{- $\mathrm{WHO}$}

- 조류 인플루엔자 바이러스 감시 및 방역, 감염 감시 기술 지원 등

- 각국의 지원 자금으로 해당 국가와 협의하여 조류 인플루엔자 예방 및 대책 사업 추진 및 기술 지원

- FAO

- 전문가 파견 및 각국 지원사업 기술 지원 및 자문

- 미국 : 총 US $\$ 11$ 백만

- 조류 인플루엔자 조기 경보 및 초기 대응 지 원 프로그램

- 커뮤니케이션 및 국민인식 제고 프로그램 등

- 전문가 파견 등

\section{- 호주 : 총 US\$15.5백만}

- Tamiflu 10만정 기증, 전문가 파견, 감염 동 물 처리 기술 지원

- 주재국 정부, $\mathrm{WHO}$ 및 $\mathrm{FAO}$ 와 지원 프로그 램 협의 중임.

\section{- 일본}

- 아시아 지역을 위하여 US $\$ 135$ 백만 규모의 지원 계획을 갖고 아시아 각국, $\mathrm{WHO}, \mathrm{FAO}$, $\mathrm{OIE}$ (국제수의 사무국)과 사업 추진 중임.
※ OIE를 통하여 국가수의 서비스, 긴급계획, 홍 보 시스템 구축 등의 사업을 추진

※ $\mathrm{WHO}$ 를 통하여 감시능력 구축을 위한 프로그 램 추진

- 그 외 수의전문가 지속적으로 파견

- 캐나다

- US\$10백만을 지원키로 약속

- $\mathrm{WHO}$ 통해서 앞으로 5 년간 감염 질병 대책 프로그램 추진 계획임.

\section{- 네덜란드}

- 주로 양자 회의를 통하여 지원 프로그램을 추진

- 농업부와 현장조사 사업 추진(백신 주사 효 과성 분석 등)

- 한국

- 조류 인플루엔자 진단시약(US $\$ 25$ 만 상당, 2005.11) 지원

※ (주)에스디에서 주재국 농업부에 기증

- 세계은행 및 $\mathrm{EU}$

- 지난 1월 16-17일 북경에서 개최된 국제회 의에서 인도네시아에 US $\$ 12$ 백만을 지원키 로 약속 